\title{
What matters most to patients when they assess quality of their care?
}

\author{
Rein Lepnurm ${ }^{1}$, Debora Voigts ${ }^{1}$, Margaret Lissel ${ }^{1}$, Roy T. Dobson ${ }^{2}$, Lynnette L. Stamler ${ }^{3}$ \\ 1. MERCURi Research Group, University of Saskatchewan, Saskatoon, Saskatchewan, Canada.2. College of Pharmacy \& \\ Nutrition, University of Saskatchewan, Saskatoon, Saskatchewan, Canada.3.College of Nursing, University of \\ Saskatchewan, Saskatoon, Saskatchewan, Canada
}

Correspondence: Rein Lepnurm. Address: MERCURi Research Group, University of Saskatchewan, 107 Wiggins Road, Saskatoon, SK S7N 5E5, Saskatoon, Saskatchewan, Canada. E-mail: r.lepnurm@usask.ca

Received: August 12, 2012

DOI : 10.5430/jha.v1n2p7

Published: December 1, 2012

Accepted: September 3, 2012

URL: http://dx.doi.org/10.5430/jha.v1n2p7

\section{Abstract}

Objectives: To report the capabilities of a patient satisfaction questionnaire in capturing factors which are important to patients in their evaluations of the quality of care they receive.

Design: An experienced research officer introduced the study to all patients with defined tracer conditions in the Saskatoon Health Region from Jan to April of 2009. Patients who agreed to participate returned their completed questionnaire directly to the research officer or placed them in a special box held by the nursing unit clerk on their unit.

Measures: The instrument contained: 18 items of the General Practice Assessment Questionnaire for physicians and nurses; as well as single items capturing patient observations regarding: attentiveness of nurses; tidiness of facilities; efficiency of tests and treatments; patient comments; and a grading scale assessing overall quality of care. Contextual items covered health status, expenses, insurance and demographics. A provider care model and a client satisfaction model were constructed and tested.

Results: Almost 96 percent of eligible patients $(n=378)$ completed the questionnaire. The provider care model explained 84.2 percent of the variation in patients' assessments of overall quality; and the client satisfaction model explained 67.6 percent of the variation. The qualities of nursing and medical care were the most important factors; however, attentiveness, tidiness, efficiency, and quantified comments each explained small but significant percentages of variance in overall quality.

Conclusions: Patients consider separate dimensions in their assessments of overall quality of care. While quality of care by professionals trumps other considerations, patients also consider attentiveness, tidiness and efficiency to be important.

\section{Key words}

Patient evaluations, Quality of care, Client satisfaction, Patient satisfaction

\section{Background}

Hospital patients and their families want to be assured that they are being treated by caring and competent nurses and doctors. Asking patients how satisfied they were with the quality of care provided during their hospital stay has become a 
regular practice in accredited hospitals. Assuring patients and their families that their opinions are taken seriously is important for three reasons:

- Hospital administration needs to be able to document instances where patients indicate that doctors and/or nurses do not appear to be carrying out their work in a competent or caring manner;

- Patients who believe that they have received caring and competent care are more likely to comply with advice about prescribed medications, diet and lifestyle provided by their doctors and nurses ${ }^{[1]}$;

- Patients and families who believe that they received caring and competent care are more likely to recommend the hospital to their friends and relatives, thus enhancing the stature of the hospital in the community.

In following up patient comments citing indifferent care, several difficulties are encountered. First, many health professionals often do not think patients are qualified to judge the competency of medical or nursing care ${ }^{[2]}$. While most professionals agree that patients should have the opportunity to express their views about the care that has been provided, there is still much debate about which questions should be asked, and how they are asked. Second, there is controversy on how patients' views should be linked to improvements in quality of care ${ }^{[3]}$. Third, many health care professionals perceive patient surveys as limited to customer or client satisfaction with attentiveness or caring ${ }^{[2]}$. Nevertheless, Berwick succinctly expressed the viewpoint that patients have a right to evaluate the health care services they receive: "I don't care what you know until I know that you care" ${ }^{[4]}$.

The challenge in giving patients an effective voice is developing patient satisfaction instruments that capture aspects of care which patients believe are important; are relevant to the care provided; and can be measured in a valid, reliable and practical way. Given the central roles of doctors and nurses in the diagnosis and treatment of hospital patients, satisfaction with the care they provide should be fundamental to all patient satisfaction surveys. While patients may not have the expertise to evaluate competence directly, they do need to believe that those providing care are: thorough in carrying out technical duties; listen carefully to what patients tell them; take enough time to understand what they need; and care enough about patients to treat them individually with dignity ${ }^{[5]}$.

Furthermore, many surveys restrict their focus on either the quality of nursing or medical care, but rarely consider both in the same questionnaire. In their complementary roles, doctors have more responsibility over technical aspects of care, such as diagnostic tests and therapeutic treatments, while nurses have more responsibility over functional aspects of care, such as monitoring the patient's progress during the process of care ${ }^{[6]}$. During their hospital stays, patients are examined by doctors and nurses, get tests and treatments, eat, sleep, attend to their personal hygiene and other needs, and are visited by family and friends. While the quality of medical and nursing care are fundamental to patient satisfaction, patients' observations regarding the efficient conduct of tests and therapies, the organization of living conditions and the attentiveness to personal needs are also important ${ }^{[7]}$.

We hypothesized that patients do evaluate overall quality of hospital care with distinct components for:

- The quality of care given by the doctor seen most of the time, during their episode of care;

- The quality of care given by the nurses seen most of the time, during their episode of care;

- Observations regarding;

- Attentiveness to personal needs;

- Efficiency of tests and procedures carried out in areas other than the nursing ward; 
- General tidiness of treatment areas; and

- Comments by patients about aspects which were perceived to affect their care.

\section{Methods}

A concise patient satisfaction questionnaire containing components for: quality of care provided by doctors and nurses; observations regarding attentiveness, efficiency and general tidiness, and quantified comments, was administered to all patients with the tracer conditions of: heart attack; stroke; prostate disease and hysterectomy during Jan to April of 2009 in the three hospitals of the Saskatoon Health Region (SHR), Saskatchewan, the birthplace of Medicare in Canada. At the inception of the study the researchers of the MERCURi Research Group (MRG) met with senior hospital executives and unit managers and selected two tracer conditions: myocardial infarct and stroke because they are leading causes of death in Canada. As an academic health sciences center, best practice models of care for these patients are used at the SHR in the management of their care. In addition, the conditions of prostate disease and hysterectomy were selected for the examination of gender specific factors. Issues of confidentiality were addressed with these managers, so that ethical approval could be obtained from both the University and SHR.

Informed consent was obtained from patients in a three step process. First, arrangements were made for the Chief Research Officer of MRG to become an employee of the SHR entitling her to have access to patient names provided by the Nursing Unit Managers of the participating units. Second, the patients were provided with a brief written description of the study. Three, under the direction of the Chief Research Officer, our field officer, a retired nurse, personally introduced the study to the eligible patients as soon as a discharge decision was made, a few hours before the patient left the hospital, in the manner outlined by Larrabee and Bolden ${ }^{[8]}$.

On a typical day, the research officer introduced the study to 5 to 7 patients and most were pleased to provide their perspectives on the quality of care they received during their episode of care. Patients were offered four alternative ways of completing the questionnaire:

- alone while the research officer talked to another patient;

- alone with the research officer available to respond to questions;

- $\quad$ with the research officer reading out the items and response choices; and

- using a proxy survey with identical items that caregivers would respond to on behalf of patients (used only by 4 patients).

Patients could return their questionnaires in sealed envelopes by giving it directly to the research officer, or have a nurse, family member or friend place it in a locked drop-box for completed patient questionnaires held by the unit clerk. Two patients promised to mail their questionnaires back to the unit, but neither did.

\subsection{Measures}

Overall quality of care was measured using a single global scale resembling a grading scale from (0 to 100) which was presented to patients AFTER they had answered all the specific items related to doctors, nurses and their observations on attentiveness, tidiness and efficiency ${ }^{[9]}$.

The quality of care provided by doctors and nurses was measured using the consultation portions of the General Practice Assessment Questionnaires ${ }^{[10]}$ for doctors (GPAQ-MD) and nurses (GPAQ-RN). These two parallel questionnaires were 
developed and tested over many years ${ }^{[11,12]}$. They are widely used in the United States and are a regular part of evaluating clinical practices in the British National Health Service ${ }^{[10]}$.

Nurses attentiveness, tidiness, and efficiency in carrying out tests and therapeutic treatments were all measured using single items scored on 5 point scales (Very poor ... Very good).

Our questionnaire contained an open ended section asking the patient "Is there anything particularly good about your health care that you would like to tell us about?" "Is there anything that could be improved?" These were considered together and coded as follows:

- $\quad$ Very positive comments with no suggestions for improvement $=+2$.

- Very positive comments plus specific suggestions for improvement $=+1$.

- $\quad$ Positive comments with no suggestions for improvement $=+1$.

- $\quad$ Balanced positive and negative comments $=0$.

- $\quad$ No comments of any kind (only $27 \%$ of the respondents) $=0$.

- Comments for improvement with no positive comments $=-1$.

- $\quad$ Strong comments for improvement plus positive comments $=-1$.

- Strong comments for improvement with no positive comments $=-2$.

In this manner the open ended commentary was quantified and considered ${ }^{[13]}$.

Our questionnaire also contained several contextual items asking about:

- How informed are you about your medical condition (scored 1 to 5);

- How involved are you in making decisions about your care (scored 1 to 6);

- Compared to other people your age, would you say your health is (worse, the same or better) than other people; and

- How will your health be according to what the doctors and nurses tell you (Excellent to Very Poor) on a 6 point scale.

Finally, we hypothesized that financial considerations might affect the views of patients, so we asked 5 items about out-of-pocket expenses for health and two items about extra insurance.

\subsection{Analysis}

Analysis of the questionnaires was performed using SPSS. Cronbach tests of internal consistency were carried out to confirm the reliability of the multi-item scales. Comparisons between mean and standard deviation scores were done with Scheffe's test within the ONEWAY ANOVA procedure ${ }^{[14]}$. A tiered approach was used to establish a hierarchy among sets of independent variables with: 
- age, health status and prognosis in the control tier;

- care by doctors and nurses in the first tier,

- attentiveness, tidiness, and efficiency in the second tier, and

- involvement in clinical decisions, knowledge, and quantified comments in the last tier.

Within each tier, stepwise regression was used to determine which factors patients deemed to be most important with $\beta$ values and Coefficients of determination $\mathrm{R}^{2}$ determining the direction, and magnitude of relationships within the model ${ }^{[15]}$. To ascertain which factors were most important by gender, we ran separate stepwise regressions for the 203 males and 175 females, controlling for prognosis and health status six months prior to hospitalization.

\section{Results}

The overwhelming majority ( 378 out of $392=96.4 \%$ ) of patients agreed to participate in the study (see Table 1). Of the 14 patients who did not participate, 8 had family members present helping them pack their things, preparing to leave the hospital, including 2 who promised to complete the survey at home but did not; and 6 patients, with prostate disease did not want to complete the survey.

Table 1. Questionnaire Response Rates \& Demographics

\begin{tabular}{llllllll}
\hline Patients & Eligible & Responded & R. Rate & Mean Age & Std Dev & Males & Females \\
\hline Heart Attack & 137 & 132 & $96.4 \%$ & 67.9 & 12.7 & 97 & 35 \\
Stroke & 74 & 74 & $100.0 \%$ & 70.1 & 16.5 & 39 & 35 \\
Hysterectomy & 106 & 105 & $99.1 \%$ & 69.2 & 11.6 & 0 & 105 \\
Prostate Disease & 75 & 67 & $89.3 \%$ & 49.6 & 11.8 & 67 & 0 \\
Total & 392 & 378 & $96.4 \%$ & 63.5 & 15.7 & 203 & 175 \\
\hline
\end{tabular}

Patients assessed their overall quality of care as very good (79.0). Hysterectomy patients gave the highest assessments at (81.6) followed by prostate patients (80.1) and heart attack patients (78.5). Stroke patients gave significantly lower assessments (75.2) (see Table 2).

The average age of heart attack patients was 67.9 years and almost three-quarters of these were men (see Table 1). Stroke patients were slightly older (70.1 years) with nearly equal numbers of men and women. Men suffering from prostate disease were about the same age (69.2 years). Hysterectomy patients were the youngest group (49.6 years). For most patients, age was not significantly correlated with assessments of overall quality of care, but younger heart attack victims reported significantly lower assessments of quality (see Table 3). Most patients reported that they were about as healthy as other people of the same age and that their prognosis after treatment was good (4.4/6.0). Stroke patients reported significantly poorer prognoses (3.6/6.0). Prognosis was significantly and positively correlated with assessments of quality, especially for heart and stroke patients (see Table 3).

Patients reported the quality of care provided by the doctor they saw the most to be very good (4.8/6.0) with insignificant variation between medical conditions. Similarly, patients reported the quality of care provided by the nurses they saw the most to be very good (4.9/6.0) with insignificant variation between medical conditions (see Table 2). Both quality of care measures incorporated items addressing specific aspects of personal health needs and were found to be highly reliable with Cronbach alphas of .93 and .88 for doctors and nurses respectively, and were significantly correlated with assessments of overall quality. 
Table 2. Reliability and Distribution of Factors Important to Patients and Control Factors

\begin{tabular}{|c|c|c|c|c|c|c|c|c|c|c|c|c|c|}
\hline \multirow[t]{2}{*}{ Variable } & \multirow{2}{*}{$\begin{array}{l}\text { Number } \\
\text { of items }\end{array}$} & \multirow{2}{*}{$\begin{array}{l}\text { Cronbach' } \\
\text { s alpha }\end{array}$} & \multirow{2}{*}{$\begin{array}{l}\text { Range } \\
\text { of } \\
\text { Scale }\end{array}$} & \multicolumn{2}{|c|}{$\begin{array}{l}\text { Myocardial } \\
\text { Infarct } \\
n=132\end{array}$} & \multicolumn{2}{|l|}{$\begin{array}{l}\text { Stroke } \\
\mathrm{n}=74\end{array}$} & \multicolumn{2}{|c|}{$\begin{array}{l}\text { Hysterectomy } \\
n=105\end{array}$} & \multicolumn{2}{|c|}{$\begin{array}{l}\text { Prostate } \\
\text { Disease } \\
n=67\end{array}$} & \multicolumn{2}{|c|}{$\begin{array}{l}\text { All Patients } \\
\mathbf{n}=378\end{array}$} \\
\hline & & & & Mean & $\begin{array}{l}\text { Std } \\
\text { Dev }\end{array}$ & Mean & $\begin{array}{l}\text { Std } \\
\text { Dev }\end{array}$ & Mean & $\begin{array}{l}\text { Std } \\
\text { Dev }\end{array}$ & Mean & $\begin{array}{l}\text { Std } \\
\text { Dev }\end{array}$ & $\begin{array}{l}\text { Mea } \\
\text { n }\end{array}$ & $\begin{array}{l}\text { Std } \\
\text { Dev }\end{array}$ \\
\hline $\begin{array}{l}\text { Overall } \\
\text { Quality of } \\
\text { Care } \\
\text { provided to } \\
\text { patients }\end{array}$ & 1 & & $0-100$ & 78.5 & 10.9 & $75.2 *$ & 12.5 & 81.6 & 10.7 & 80.1 & 10.2 & 79.0 & 11.2 \\
\hline $\begin{array}{l}\text { Quality of } \\
\text { Care by } \\
\text { doctor seen } \\
\text { the most }\end{array}$ & 9 & .93 & 1 to 6 & 4.8 & .9 & 4.5 & 1.0 & 5.1 & .9 & 4.9 & .8 & 4.8 & .9 \\
\hline $\begin{array}{l}\text { Quality of } \\
\text { Care by } \\
\text { nurse(s) seen } \\
\text { the most }\end{array}$ & 9 & .88 & 1 to 6 & 4.9 & .9 & 4.6 & .9 & 5.0 & 1.0 & 4.9 & .9 & 4.9 & .9 \\
\hline $\begin{array}{l}\text { Nurses } \\
\text { Attentiveness }\end{array}$ & 1 & - & 1 to 5 & 4.6 & .7 & 4.5 & .8 & 4.5 & .9 & 4.7 & .6 & 4.6 & .7 \\
\hline Tidiness & 1 & - & 1 to 5 & 4.4 & .6 & 4.4 & .6 & 4.6 & .6 & 4.4 & .7 & 4.4 & .6 \\
\hline $\begin{array}{l}\text { Efficiency of } \\
\text { Diagnostic } \\
\text { Tests \& } \\
\text { Treatments }\end{array}$ & 1 & - & 1 to 5 & 3.9 & .9 & 3.4 & .9 & 4.0 & 1.0 & 3.8 & .8 & 3.8 & .9 \\
\hline $\begin{array}{l}\text { Involvement } \\
\text { in Treatment } \\
\text { Decisions }\end{array}$ & 1 & - & 1 to 6 & 3.5 & 1.4 & $2.9^{*}$ & 1.5 & $4.7^{*}$ & 1.1 & 4.5 & 1.3 & 3.9 & 1.3 \\
\hline $\begin{array}{l}\text { Knowledge } \\
\text { of Medical } \\
\text { Condition }\end{array}$ & 1 & - & 1 to 5 & 3.7 & 0.9 & 3.2 & 1.0 & 4.0 & 0.8 & 3.8 & 0.9 & 3.7 & 0.9 \\
\hline $\begin{array}{l}\text { Out of Pocket } \\
\text { Expenses }\end{array}$ & 5 & .73 & 1 to 5 & 1.8 & .07 & 1.6 & 0.4 & 1.8 & 0.6 & 1.8 & 0.7 & 1.7 & 0.6 \\
\hline $\begin{array}{l}\text { Extra } \\
\text { Insurance }\end{array}$ & 2 & .86 & 1 to 5 & 2.4 & 1.5 & 2.1 & 1.5 & 3.0 & 1.4 & 2.4 & 1.4 & 2.5 & 1.5 \\
\hline $\begin{array}{l}\text { Quantified } \\
\text { Comments }\end{array}$ & 1 & - & 1 to 5 & 3.4 & 1.0 & 3.4 & 1.0 & 3.4 & 1.1 & 3.3 & 1.0 & 3.4 & 1.0 \\
\hline Controls & & & & & & & & & & & & & \\
\hline $\begin{array}{l}\text { Age of } \\
\text { Patient }\end{array}$ & & - & 19 to 94 & 67.9 & 12.7 & 70.1 & 16.5 & $49.6^{*}$ & 11.8 & 69.2 & 11.6 & 63.5 & 15.7 \\
\hline $\begin{array}{l}\text { Health } 6 \\
\text { months } \\
\text { before } \\
\text { treatment }\end{array}$ & 1 & - & 1 to 3 & 2.3 & .7 & 2.3 & .7 & 2.0 & .8 & 2.3 & .8 & 2.2 & .7 \\
\hline $\begin{array}{l}\text { Prognosis } \\
\text { after } \\
\text { Treatment }\end{array}$ & 1 & & 1 to 6 & 4.0 & .9 & $3.6^{*}$ & .9 & 5.0 & .8 & 4.7 & .8 & 4.4 & 1.0 \\
\hline
\end{tabular}

* Significance level between 0.01 and 0.05 using Scheffe's test.

Patients also reported that nurses were exceptionally attentive to their needs (4.6/5.0) and that facilities were very clean and orderly (4.4/5.0) with very little variance between medical conditions (see Table 2). However, patients reported that there was room for improvement in efficiency, with ratings of 3.8 out of 5.0 and no significant variances. Attentiveness, tidiness and efficiency were all significantly correlated with overall assessments of quality (see Table 3 ).

Stroke patients reported significantly lower levels of involvement with clinical decisions (2.9/5.0) compared to other patients, while hysterectomy (4.7/5.0) and prostate (4.5/5.0) patients reported significantly higher levels of involvement. Patients reported being reasonably knowledgeable about their medical conditions (3.7/5.0), with stroke patients knowing a bit less (3.2/5.0) than patients with the other medical conditions. Involvement in treatment decisions was significantly correlated with assessments of quality for heart, stroke and hysterectomy patients, but not for patients with prostate 
disease. Knowledge about their medical condition was significantly correlated with assessments of quality for all patients (see Table 3).

Table 3. Correlations

\begin{tabular}{|c|c|c|c|c|}
\hline \multirow{3}{*}{$\begin{array}{l}\text { Overall Quality of Care } \\
\text { provided to you on the Unit }\end{array}$} & \multicolumn{4}{|c|}{ Correlations } \\
\hline & $\begin{array}{l}\text { Myocardial } \\
\text { Infarct }\end{array}$ & Stroke & Hysterectomy & Prostate Disease \\
\hline & $n=132$ & $n=74$ & $\mathrm{n}=105$ & $n=67$ \\
\hline Age of Patient & $-0.223^{*}$ & -.016 & .096 & -.177 \\
\hline $\begin{array}{l}\text { Health } 6 \text { months before } \\
\text { treatment (H6monthsPrior) }\end{array}$ & .143 & .165 & .133 & .133 \\
\hline Prognosis after Treatment & $0.261 * *$ & $0.316^{* *}$ & $0.232 *$ & $0.252 * *$ \\
\hline $\begin{array}{l}\text { Quality of Care by doctor seen } \\
\text { the most (DOCQUAL) }\end{array}$ & $0.718 * * *$ & $0.858 * * *$ & $0.636^{* * *}$ & $0.811 * * *$ \\
\hline $\begin{array}{l}\text { Quality of Care by nurse(s) seen } \\
\text { the most (NURSEQUAL) }\end{array}$ & $0.711 * * *$ & $0.819^{* * *}$ & $0.800 * * *$ & $0.872 * * *$ \\
\hline Nurses Attentiveness & $0.614 * * *$ & $0.617 * * *$ & $0.631 * * *$ & $0.587 * * *$ \\
\hline Tidiness & $0.463 * * *$ & $0.676^{* * *}$ & $0.573 * * *$ & $0.574 * * *$ \\
\hline $\begin{array}{l}\text { Efficiency of Diagnostic Tests \& } \\
\text { Treatments }\end{array}$ & $0.710^{* * *}$ & $0.594 * * *$ & $0.640 * * *$ & $0.670^{* * *}$ \\
\hline $\begin{array}{l}\text { Involvement in Treatment } \\
\text { Decisions }\end{array}$ & $0.274 * *$ & $0.368^{* * *}$ & $0.198^{*}$ & 0.113 \\
\hline $\begin{array}{l}\text { Knowledge of Medical } \\
\text { Condition }\end{array}$ & $0.412 * * *$ & $0.336^{* * *}$ & $0.217^{*}$ & $0.375 * * *$ \\
\hline Out of Pocket Expenses & -0.071 & -0.165 & -0.005 & -0.030 \\
\hline Extra Insurance & $-0.176^{*}$ & -0.022 & -0.050 & 0.173 \\
\hline Quantified Comments & $0.554^{* * *}$ & $0.553^{* * *}$ & $0.516^{* * *}$ & $0.604 * * *$ \\
\hline
\end{tabular}

Significance levels $* * *(\mathrm{p}=.000) * *(\mathrm{p}=.001-.009) *(\mathrm{p}=.010-.050)$

Most patients reported minor out-of-pocket health expenses (1.7/5.0) and half of the patients reported having extra-insurance (2.5/5.0) to cover expenses not covered by Canadian national health insurance. Both financial measures were found to be reliable. Only the lack of extra-insurance for heart attack patients was significantly correlated with their assessments of overall quality. Almost three-quarters of the patients (73\%) made comments about their episode of hospital care and most were positive (3.4/5.0) and highly significantly correlated with their assessments of overall quality (see Table 2).

\section{Models of quality of care from the patient's perspective}

In assessing the quality of care provided to them during their episode of hospital care, patients regarded quality of care provided by nurses to be most important accounting for half of the total variation in overall quality (52.5\%) followed by the quality of care provided by doctors $(15.7 \%)$ (see Table 4). Tidiness (2.8\%), efficiency $(1.2 \%)$ attentiveness to needs $(0.6 \%)$ and quantified comments $(0.4 \%)$ explained small but significant variances in overall assessments of quality for a total of 84.2 percent. Financial issues did not influence patients' assessments of quality. Female patients reported the same factors in the same order of importance, except attentiveness was more important than efficiency explaining a total of $86.2 \%$ of the variation in their assessments of overall quality. Male patients reported the quality of care provided by 
doctors to be the most important accounting for $55.2 \%$ of the total variation in overall quality, followed by the quality of care provided by nurses $(13.2 \%)$, tidiness $(2.6 \%)$ and efficiency $(0.7 \%)$ for a total of $83.2 \%$ of the variation in their assessments of overall quality.

Table 4. Factors of Quality which are Important to Patients

\begin{tabular}{|c|c|c|c|c|c|c|c|}
\hline \multirow{2}{*}{\multicolumn{2}{|c|}{$\begin{array}{l}\text { Dependent } \\
\text { Variable: Overall } \\
\text { Assessment of } \\
\text { Quality }\end{array}$}} & \multirow{2}{*}{$\begin{array}{l}\text { Cumulative } \\
\text { Adjusted } R^{2}\end{array}$} & \multicolumn{2}{|c|}{ Change Statistics } & \multirow{2}{*}{$\begin{array}{l}\begin{array}{l}\text { Standardized } \\
\text { Coefficients }\end{array} \\
\text { Beta }\end{array}$} & \multirow{2}{*}{$\mathbf{T}$} & \multirow{2}{*}{ Sig. } \\
\hline & & & \multirow{2}{*}{$\begin{array}{l}\text { Incremental } \\
\mathbf{R}^{2} \\
.103\end{array}$} & \multirow{2}{*}{$\begin{array}{l}\text { F Change } \\
43.1\end{array}$} & & & \\
\hline 1 & Prognosis & .100 & & & .020 & .92 & .360 \\
\hline 2 & H6monthsPrior & .109 & .010 & 4.4 & -.014 & -.64 & .522 \\
\hline 3 & NURSEQUAL & .635 & .525 & 541.6 & .369 & 11.82 & .000 \\
\hline 4 & DOCQUAL & .793 & .157 & 285.4 & .372 & 13.63 & .000 \\
\hline 5 & Tidiness & .820 & .028 & 58.3 & .157 & 6.67 & .000 \\
\hline 6 & Efficiency & .832 & .012 & 27.1 & .122 & 4.50 & .000 \\
\hline 7 & Attentiveness & .838 & .006 & 14.7 & .097 & 3.45 & .001 \\
\hline 8 & Quantified Cmts & .842 & .004 & 9.4 & .075 & 3.06 & .002 \\
\hline
\end{tabular}

$* \mathrm{df}=369$

To focus on client satisfaction issues, a second model excluding direct care provided by physicians and nurses scales (GPAQ-MD and GPAQ-RN) was tested resulting in a model that explained 67.6 percent of variance in patient assessment of quality (see Table 5). Within the client satisfaction model, significant individual items include efficiency $36.0 \%$, attentiveness (11.2\%), tidiness (6.4\%), quantified comments (2.8\%) and knowledge about medical conditions ( $0.5 \%)$.

Table 5. Factors of Client Satisfaction which are Important to Patients

\begin{tabular}{|c|c|c|c|c|c|c|c|}
\hline \multirow{2}{*}{\multicolumn{2}{|c|}{$\begin{array}{l}\text { Dependent Variable: } \\
\text { Overall Assessment } \\
\text { of Quality }\end{array}$}} & \multirow{3}{*}{$\begin{array}{l}\text { Cumulative } \\
\text { Adjusted } \mathbf{R}^{2}\end{array}$} & \multicolumn{2}{|c|}{ Change Statistics } & \multirow{3}{*}{$\begin{array}{l}\begin{array}{l}\text { Standardized } \\
\text { Coefficients }\end{array} \\
\text { Beta } \\
.122\end{array}$} & \multirow{3}{*}{$\begin{array}{l}\mathbf{T} \\
3.89\end{array}$} & \multirow{3}{*}{$\begin{array}{l}\text { Sig. } \\
.000\end{array}$} \\
\hline & & & \multirow{2}{*}{$\begin{array}{l}\text { Incrementa } \\
\mathbf{l} \mathbf{R}^{2} \\
.103\end{array}$} & \multirow{2}{*}{$\begin{array}{l}\text { F Change } \\
43.1\end{array}$} & & & \\
\hline 1 & Prognosis & & & & & & \\
\hline 2 & H6monthsPrior & .109 & .010 & 4.4 & -.004 & -.15 & .881 \\
\hline 3 & Efficiency & .469 & .360 & 255.5 & .326 & 9.00 & .000 \\
\hline 4 & Attentiveness & .581 & .112 & 100.4 & .269 & 7.79 & .000 \\
\hline 5 & Tidiness & .644 & .064 & 67.5 & .245 & 7.40 & .000 \\
\hline 6 & Quantified Cmts & .671 & .028 & 32.1 & .186 & 5.46 & .000 \\
\hline 7 & Knowledgeable & .676 & .005 & 5.9 & .079 & 2.44 & .015 \\
\hline
\end{tabular}

$* \mathrm{df}=370$

\section{Discussion}

Patients do consider more than care by doctors and nurses in their assessment of overall quality during their hospitalization; but factors such as efficiency, attentiveness, and tidiness appear to be of less importance. However, those less important factors should not be ignored. Collectively, these factors can be considered as aspects of client satisfaction and provide a competing model in the assessment of overall quality ${ }^{[1,16]}$. Furthermore, there is overlap in the two overall quality models as elements of attentiveness and efficiency are embedded in the items describing consultations between patients and their care providers. 
Most patients are no longer willing to be passive recipients of care and services; they want to express their concerns ${ }^{[17]}$ as the high response rate achieved in this study suggests. Many patients are knowledgeable about their medical conditions and are involved in decisions regarding their care, especially when their medical condition is serious ${ }^{[18,19]}$. This study showed that involvement with care decisions and knowledge about their medical condition are important. Heart and stroke patients considered knowledge of their medical condition and involvement with treatment decisions to be more significantly related to their assessments of quality, than patients with prostate disease or hysterectomy, despite being less knowledgeable and having less involvement in decisions. It may be argued that heart and stroke conditions are more complex conditions than prostate disease and hysterectomy and require more time to explain than clinicians are able to devote ${ }^{[2]}$. However, more patient-centered care is likely to increase compliance with follow-up care instructions ${ }^{[1]}$ leading to acceptance of more responsibility for their own care ${ }^{[20,21]}$.

Patient expectations of quality are high and overall assessments of quality of care were very good (79.0). Nevertheless, there is room for improvement, particularly for stroke care (75.2). Expectations should not be confused with customer satisfaction. This study clearly showed that patients place a great deal of faith in doctors and nurses with expectations of cleanliness, efficiency and attention to their needs, fitting in at a secondary level. And these secondary expectations were met, most of the time, as reflected in the preponderance of positive over negative comments and very good ratings for attentiveness and tidiness. There is still room for improvement in ratings of efficiency (3.8/5.0), with stroke care needing the most attention (3.4/5.0); however, these ratings are still good and patients are rational in their perspectives of what is most important in overall assessments of quality.

Prognosis was significantly and positively correlated with assessments of quality, especially for heart and stroke patients. While age is often used as a control, the regression analysis showed that prior health status and prognosis, often correlated with age, are more important as controls than age alone ${ }^{[22]}$.

Given the presence of comprehensive national health insurance in Canada it was not surprising that financial considerations did not influence overall assessments of quality for most patients' however, for heart attack patients the lack of extra-insurance significantly and negatively affected assessments of overall quality. Placing this finding in context, it should be recognized that governments pay about 70 percent of the total costs, with the remainder as out-of-pocket expenses or covered by supplementary health insurance ${ }^{[23]}$.

In conclusion, patients are able to assess quality of care in a rational manner and the validity of the measures used, were supported. This study also supported including patient observations of attentiveness, tidiness and efficiency of carrying out tests and treatments in addition to assessing quality of care by doctors and nurses, to make patient evaluations of overall quality more complete. Through comprehensive patient assessments of greater validity, reliability and sensitivity, researchers and clinicians can move forward in their work to link the views of patients' with improvements to quality of care.

\section{Acknowledgements}

This study of patients was part of the "Managing Quality in Canadian Hospitals (MQCH) Study" funded by an operating grant from the Canadian Institutes for Health Research (FRN: 84240).

\section{References}

[1] Otani K. How Patient Reactions to Hospital Care Attributes Affect the Evaluation of Overall Quality of Care, Willingness to Recommend, and Willingness to Return Journal of HealthCare Management. 2010; 55(1): 25-37.

[2] Franks P, Fiscella K, Shields C, Meldrum S, Duberstein P, Jerant A, et al. Are Patients' Ratings of Their Physicians Related to Health Outcomes? Annal of Family Medicine. 2005; 3(3): 229-34. PMid:15928226 http://dx.doi.org/10.1370/afm.267 
[3] Sitzia J. How valid and reliable are patient satisfaction data? An analysis of 195 studies. International Journal of Quality Health Care. 1999; 11(4): 319-28. PMid:10501602 http://dx.doi.org/10.1093/intqhc/11.4.319

[4] Berwick D. Presentation. 17th Annual Forum on Quality Improvement in Health Care, Institute for Health Improvement; December 12; Orlando2005.

[5] Staniszewska S, Ahmed L. The concepts of expectation and satisfaction: do they capture the way patients evaluate their care? Journal of Advanced Nursing. 1999; 29(2): 364-72. PMid:10197936 http://dx.doi.org/10.1046/j.1365-2648.1999.00897.x

[6] Shen H-C, Chiu H-T, Lee P-H, Hu Y-C, Chang W-Y. Hospital environment, nurse-physician relationships and quality of care: questionnaire survey. Journal of Advanced Nursing. 2010; 67(2): 349-58. PMid:21044136 http://dx.doi.org/10.1111/j.1365-2648.2010.05502.x

[7] Schmidt L. Patients' perceptions of nursing care in the hospital setting. Journal of Advanced Nursing. 2003; 44(4): 393-9. PMid:14651711 http://dx.doi.org/10.1046/j.0309-2402.2003.02818.x

[8] Larrabee J, Bolden L. Defining Patient-Perceived Quality of Nursing Care. Journal of Nursing Care Quality. 2001; 16(1): 34-60. PMid:11668855 http://dx.doi.org/10.1097/00001786-200110000-00005

[9] Lepnurm R, Dobson R, Stamler L, Persaud D, Keegan D, Brownbridge B. The contribution of work environment to nurses'assessments of the quality of patient care. Healthcare Management Forum. 2012; 25: 70-79. PMid:22931012 http://dx.doi.org/10.1016/j.hcmf.2012.04.002

[10] GPAQv3. GPAQv3 Manual for General Practice Assessment Questionnaire (GPAQ-MD and GPAQ-RN) Section 2.1 Terms for use [Internet]. University of Cambridge/University of Manchester. 2011 [cited 2011 December]. Available from: www.gpaq.info.

[11] Ramsey J, Campbell J, Schroter S, Green J, Roland M. The General Practice Assessment Survey (GPAS): tests of data quality and measurement properties. Family Practice. 2000; 17: 372-9. PMid:11021894 http://dx.doi.org/10.1093/fampra/17.5.372

[12] Safran D, Kosinski M, Tarlov A, Rogers W, Taira D, Lieberman N, et al. The Primary Care Assessment Survey: Tests of Data Quality and Measurement Performance. Medical Care. 1998; 36(5): 728-39. PMid:9596063 http://dx.doi.org/10.1097/00005650-199805000-00012

[13] Elwyn G, Buetow S, Hibbard, M. W. Respecting the subjective: quality measurement from the patient's perspective. British Medical Journal. 2007; 335: 1021-2. PMid:18007003 http://dx.doi.org/10.1136/bmj.39339.490301.AD

[14] Hair J, Black W, Babin B, Anderson R, Tathan R. Multivariate Data Analysis. 6 ed. Upper Saddle River, New Jersey: Pearson -Prentice Hall. 2006.

[15] Tabachnick B, Fidell L. Using Multivariate Statistics. New York: Harper-Collins. 2007.

[16] Hudak P, McKeever P, Wright J. The metaphor of patients as customers: Implications for measuring satisfaction. Journal of Clinical Epidemiology. 2003; 56: 103-8. http://dx.doi.org/10.1016/S0895-4356(02)00602-9

[17] Landzelius K. Patient organization movements and new metamorphoses in patienthood (editorial). Social Science and Medicine. 2006; 62: 529-37. http://dx.doi.org/10.1016/j.socscimed.2005.06.023

[18] Schoenfelder T., Klewer J., Kugler J. Determinants of patient satisfaction: a study among 39 hospitals in an in-patient setting in Germany. International Journal for Quality in Health Care. 2011; 23 (5): 503-509. PMid:21715557 http://dx.doi.org/10.1093/intqhc/mzr038

[19] Sørlie V, Torjuul K, Ross A, Kihlgren M. Satisfied patients are also vulnerable patients-narratives form an acute care ward.Journal of Clinical Nursing. 2006; 15: 1240-1246. PMid:16968428 http://dx.doi.org/10.1111/j.1365-2702.2006.01352.x

[20] Weinstein J, Clay K, Morgan T. Informed Patient Choice: Patient-Centered Valuing of Surgical Risks and Benefits. Health Affairs. 2007; 26(3): 726-230. PMid:17485750 http://dx.doi.org/10.1377/hlthaff.26.3.726

[21] Légaré F, Stacey D, Gagnon S, Dunn S, Pluye P, Frosch D, et al. Validating a conceptual model for an inter-professional approach to shared decision making: a mixed methods study. Journal of Evaluation in Clinical Practice. 2011; 17: 554-64. PMid:20695950 http://dx.doi.org/10.1111/j.1365-2753.2010.01515.x

[22] Zhang Y, Rohrer J, Borders T, Farrell T. Patient satisfaction, self-rated health status, and health confidence: an assessment of the utility of single item questions. American Journal of Medicine and Quality. 2007; 22(8): 42-52. PMid:17227877 http://dx.doi.org/10.1177/1062860606296329

[23] CIHI. Public and Private-Sector Shares of Total Health Expenditure (fig 8) in Total Health Expenditure, Canada, 1975 to 2010. Canadian Institute for Health Information [Internet]. 2012 [cited 2012 April]. Available from: www.cihi.ca. 